$\begin{array}{cr}\text { A } & 2 \\ \text { B } & 6 \\ \text { C } & 4 \\ & \\ \text { D } & 2\end{array}$

図6 満足度

たものが 2 例ある. このうち 1 例は, 疼痛は改善した ものの跛行が術前より強くなり，ために腰痛を覚える ようになったものと, 他の 1 例は疼痛の改善が得られ なかったてとを不満としている.両者とも亿両例槛患 例である。

次にレ線像についてみると, 術前関鉴の不適合性の 他に，主として曰蓋側荷重部に骨硬化像のあったもの が, 術後減少又は消失したものが 5 例あるが, 関節裂 隙の開大が明らかにみられるものは 2 例にすぎない。
しかしレ線上で改善のみられるものは，成績も優良例 が殆んどである。

結語

以上骨切術の成績をのべてきたが，乙れをその他の 手術の成績と比較しても決して劣ってはいない，ただ その適応にはかなりの違いがみられる．われわれの骨 切症例では，比較的良好な可動性をもち，O. A. 変化 も比較的軽度であるが, 将痛が強い若年者で, X線像 により関節適合性の改善が見込まれるものに対して行 なわれている.

骨切術による除痛のメカニズムについては多くの説 明があるが，われわれの症例のように若年者二次性 O. A. 患者に対しては, 関節適合性の改善が充分に行 なわれるならば, 筋緊張の必要以上の低下は, 跛行を 長びかせるととになりうる，術前の適正な骨切角度の 決定と，それに従った定量的骨切操作が大切であると 考えられる。

\title{
当教室における変形性股関節症の治療経験
}

鹿児島大学整形外科教室

$\begin{array}{llllll}\text { 宮 } & \text { 崎 淳 弘 - 田 } & \text { 中 源 郎 } \\ \text { 日 } & \text { 高 } & \text { 恒 彦・桑 畑 昭 洋 } \\ \text { 横 } & \text { 峯 } & \text { 佐 䯚 } & & & \end{array}$

\section{The Osteoarthrosis of the Hip Joint Treated Surgically at our Clinic}

By

\author{
A. Miyazaki, M. Tanaka, T. Hidaka, \\ A. Kuwabata and S. Yokomine \\ Department of Orthopaedic Surgery, Faculty of Medicine, \\ Kagoshima University
}

Between 1963 and 1973, 49 cases of osteoarthrosis of the hip joint have been treated surgically at our clinic.

35 patients ( 39 hips) out of 49 had been clinically followed up to 10 years after surgery.

5 patients out of 35 was excluded in this series as they have already been reported as undergone total hip replacement.

This operative methods employed in this series were subtrochanteric and interochanteric osteotomy in 12 and 3 cases respectively, release operation in 8 cases, arthroplasty in 2 
cases, arthrodesis in 3 cases and bone transplantation in 2 cases.

24 patients satisfied with the result, and the others unsatisfied.

\section{はじめに}

変形性股関節症に対し, われわれの教室に於て, 昭 和 39 年より昭和 48 年迄に, 外科的治療を行なった症 例の追跡調查を行なった。なお, 全人工関節置換術に ついては，第 48 回本学会において報告したので今回 は除く。

\section{調查対象および調查方法}

調查対象は, 搔爬骨移植術 2 例, 等解離術 14 例, 日蓋形成術 3 例, 大転子下降術 1 例, 骨切り術 23 例, 関節形成術 13 例, 関節固定術 5 例, 計 49 例 61 関 節で, 男女比は $1: 2.5$, 平均年令は 32.4 才である. 1 次性 6 例, 2 次性 43 例である. 今国 follow-up に 応じたものは 35 例 39 関節で（全人工.関節䈯換術を含 む)，直接検診 21 例，アンケート 14 例であった。 男女比は 1:2, 平均年令は 33 才, 平均 follow-up 期間は 5 年 6 力月である (図1).

\section{術式とその成績}

施行された術式は, 骨切り術 16 例, 筋解離術 7 例, 関節形成術 1 例, 関節固定術 3 例, 搔爬骨移植術 2 例，人工骨頭置換術 1 例，である，それぞれの成績 は, 転子下骨切り術 10 例中転子下外反骨切り術 8 例, 転子下内反骨切り術 2 例で, 転子下外反骨切り術は19 才以下に 7 例, 30 才台に 1 例行なわれ，平均 followup 期間は, 8 年 7 力月, 術前平均点 61 点, 術後平均 点 86 点である. 転子下内反骨切り術は, 20 才台に 2 例行なわれ，期待した效果はなかった。転子間内反骨 切り術は, 20 才女子に 1 例行なわれ, 術前 70 点が, 術後 85 点と改善された。転子間外反骨切り術は, 3 例飞行なわれ, 術前平均点 47 点より術後平均点 81 点 と改善され，平均年令は 16.2 才である。筋解離術は 7 例飞行なわれ, 平均年令 52.7 才, 平均 follow-up 期間は 5 年 5 力月である. O’Malley 法は 5 例に対し 行なわれ, 術前平均点 48 点が, 術後平均点 66 点と 改善されている.Voss 法の 2 例においては，1例が 不変， 1 例は 35 点が 88 点と改善された。他の手術の 結果については，大方が満足度 $\mathrm{b}$ と答えているが， 1 例転子下移動骨切り術を行なった例において，淽足度

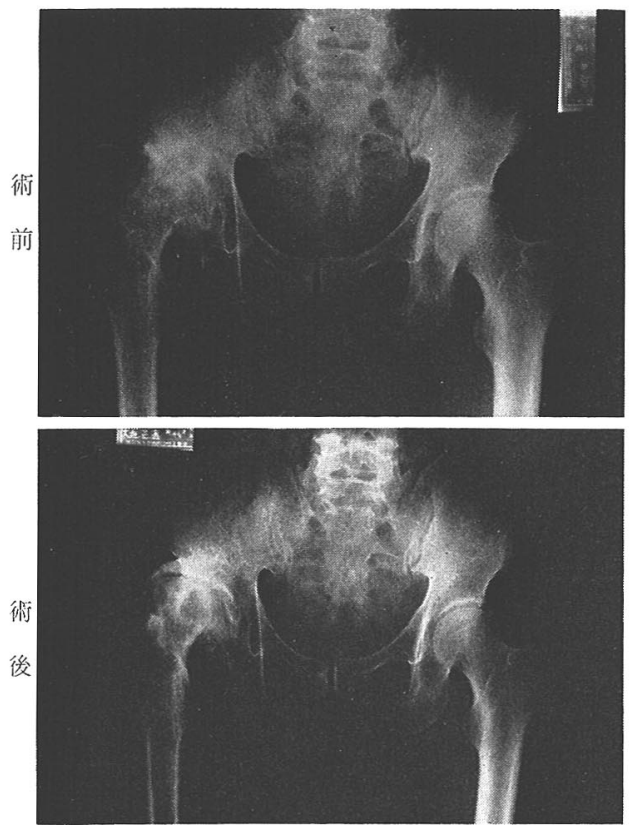

図 1 症例 (1)

d と答えた。

各手術法の評洒基準の平均上昇率を备基準の術後点 一各基準の術前点とすると, 転子下外反骨切り術てお いて, 疼痛 $40.6 \%$, 歩行能力 $37.5 \%$, ADL $18.1 \%$ と上昇しているが，可動性は 8 人中 4 人迄が低下し， 上昇率は一 $-0.6 \%$ である. 满足度は全症例 $\mathrm{b}$ と答えて いる. 転子下内反骨切り術は全ての基準共上昇はみら れず，満足度は 2 例共 $\mathrm{c}$ 子答えた。転子下移動骨切り 術は 2 例に対し行なわ机，1例は疼痛が $20 \%$, 可動 性が 15 \% 上昇したが，歩行能力およで ADL は不変 であった。満足度は b と答えた。1 例は骨䯑炎炎後の 2 次性変股症に対し行なわれたが, 術後強直を来たし， 疼痛は $100 \%$ 上舁であったが他は全て0となり満足 度 $\mathrm{d}$ であった。転子間外反骨切り術は 3 例飞対し行な われ，疼痛 $50 \%$ ，歩行能力 $50 \%$ と共に上昇している が, 可動性, ADL, は共に1\%上昇と，あまり改善 されなかった。転子間内反骨切り術は 1 例で, 疼痛 $25 \%$ ，ADL $25 \%$ と上㫤しているが，可動性は不変 であった。漩解離術は 7 例で, O’Malley 法を行なっ た 5 例において, 疼痛 $30 \%$, 歩行能力 $5 \%$, 可動性 
4\%, ADL $12.5 \%$ と, 疼痛除去に著効を示してい る. Voss 法の 2 例飞おいて, 1例は疼痛 $50 \%$, 歩 行能力 $50 \%$, 可動性 $70 \%, \mathrm{ADL} 45 \%$ とすべて上昇 しているが，1例は将痛 $25 \%$, 可動性 $10 \%$ と上昇し たが，歩行能力 $-25 \%$, ADL $-30 \%$ と下降した。

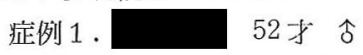

現病歴 38 才の時発症，しだいに右股関節痛，跛 行を呈す. 43 才 の時 2 次性変形性股関節症の骖断下 に Voss の手術施行. 術前評価は 35 点, 術後 9 年 10 力月の現在 88 点である. 洔に腰痛, 滕関節痛を訴 えるが満足度はbである。レ線にて術前目蒤にあった 襄胞栐陰影は消失したが, 骨頭側では增大しており, 関節裂腙は拡大している.

\section{症例 2 23才 우 \\ 主訴 跛行および右股関節痛}

既往歴 10 才時右大腿骨骨折

現病歴 右大腿骨骨折に対し骨接合術を受けた後, 右股関節痛および跛行出現. 14 才の時, 外傷後の 2 次性変形性股関節症の診断下に転子下外反骨切り術を 施行. 術前評価は 60 点, 術後 8 年の現在 85 点であ る. 桨痛は不変であるが, 歩行能力, 可動性, ADL は著明に改善されている，本症例は外反膝があり，時

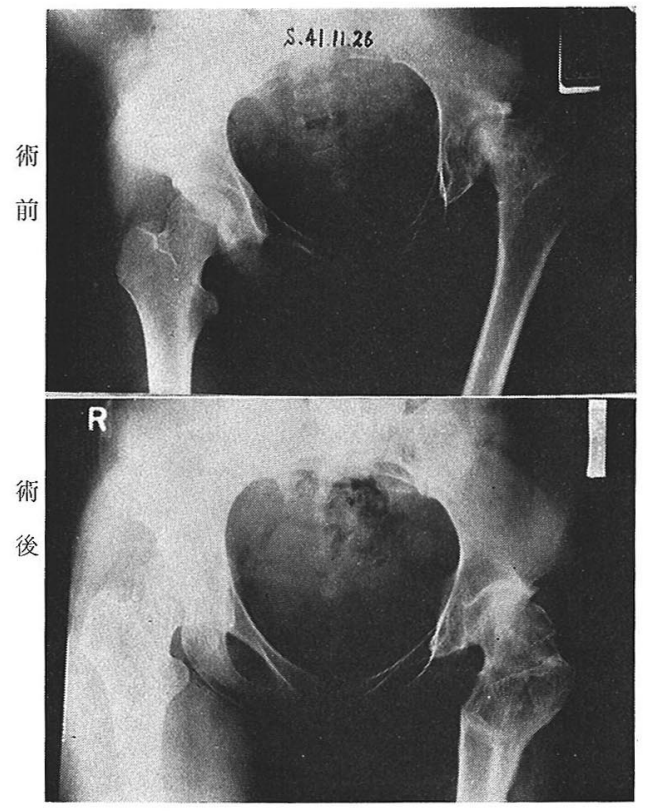

図 2 症例 (2)

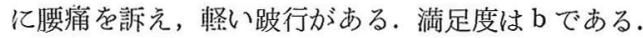
レ線にて術前の aseptic necrosis の状態は改善さ れ，関節裂隙は良く保たれている。

$$
\text { 考案 }
$$

変形性股関節症に対する手術法は，嶋によると

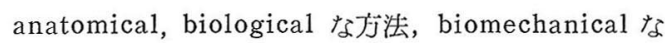
方法, spare-parts 的な方法に大别され，現在では， anatomical, biological な方法がとられる事は稀と なっている.われわれの症例は，2 例の掻爬骨移植術 を除き全て biomechanical, spare-parts 的な方法 であった，何れも愁訴のすべてを改善させる事は因難 であった，骨切り術に扔ては，転子間骨切り術より 名転子下骨切り術が多く行なわれ，特飞10才台の転 子下外反骨切り術が多く，その成績は，広畑らは悲観 的であると斏觜しているが，われわれは疼痛，歩行能 力の大ウな改善をみた。しかし可動性は低下した例が 多く，ADL は僅かではあるが改锌された例が多かっ た. 転子下骨切り術の目的とする所は 1) 大転子の外 下方移動により, 中, 小㛭筋の機能が改善され, Trendelenburg 症候が軽快する，2）骨切り術によ り骨盤支持力を增し, 起立, 歩行時の骨盤の傾きを柽減 寸る．３）下肢の機能軸が体幹の正中線（重心線）に 近づくため骨盤の横摇れが軽減する，などである．わ れわれの症例では主に1）と３）および良好な関節適 合性, 生物学的刺激の効果莫目的として, 主に前関節 症の症例湤行し，比較的良好な結果を得た。好結果 の原因として 1 ）術前比較的関節裂隙の保たれてい る症例に行なった事．2）目蓋と骨頭との良好な適合 性が得られた事があげられる。 LcDetenbeck は，臨 床的索果は, 術後の関節裂隙の改善, 術前の満足す心゙ き関節裂除の保持であると述べ, Adam, Spence ら は, 生物学的刺激と, 関節檤合性の改善を目的とし, Campbell, Jacson らは, 変形の镉正を重視してい る, 更に Otto!enghi は, revascularization の効果 をあげている，以上の事より 10 才台の pre-OA に対 して閂節裂隙が比較的保たれ，関節適合性が外反によ り改善されるならば，転子下外反骨切り術によっても 良好な結果が得られる。しかしながら，術後の滕への 影響などの点から転子間骨切り術が優れていると思わ れる。

骨切り術全体としては, 疼痛, 歩行能力に対しては 有效であったが，可動性に対する効果は少なく，にも 
拘らず，殆んどが満足度 $\mathrm{b}$ と答えたのは笗痛が除かれ たからである. 又転子下外反骨切り術を行なった症例 は, 現在殆んどが 20 才台に達し, 今後の追跡が必要 である、筋解髉術については, O'Malley 法 5 例, Voss 法 2 例を行なったが，何れも疼痛除去には有効 であったが，歩行能力，可動性，ADL に関しては余 り改善を見なかった。 疼痛の点では, 横崎らは $97 \%$, 井沢らは $86.9 \%$ 改善を報告している．われわれの 症例でも $100 \%$ の改善があった，水野，上野，井沢ら は, 腸腰筋切離と外転筇群の温存を唱えているが, わ れわれの Voss 法を行なった 1 例は術後 9 年 10 力月 の現在, 時に腰痛, 膝関節痛は訴えるが, 股関節痛は 全くなく，関節裂隙も保たれ，健常人に近い生活を送 っている. 又 1 例は, 除痛の効果はみられたが，他は すべで低下し，満足度 $\mathbf{c}$ と答えた，O’Malley 法にお いては, 歩行能力の低下したもの 1 例, 可動性の低下 したもの1例であり, 疼痛, ADL は全て改善されて いる. しかし 4 年以上を経た症例では，時に疼痛の再 現を見て，横崎らのいうごとく 5 年以上を経ると，效 果の堿少は生ずるものの，一応試みて然るべき方法で あろう.
結語

われわれは，昭和 39 年より昭和 48 年迄，当教室に おいて, 変形性股関節症に対し, 外科的治療を行なっ たもの 35 例 39 関節のうち全人工関節置換術を除いた 30 例 30 関節の追跡調査の結果を若干の文献的考察を 加え報告した.

\section{参 考 文 献}

1) Adam and Spence: J. B. J. S. 40-B: 219, 1958.

2) Campbell and Jackson: J. B. J. S. 38-B : No. 2, 1956.

3）広畑・他：日整会誌. 48：159-167, 1970 .

4) 井沢 - 他 - 整形外科, 20:10, 1969.

5）河邨文一郎：臨床整形外科全書. 4：245, 金原 出版, 1963.

6) Lc Detenbeck et al. : J. B. J. S. 54-A : $1351,1972$.

7）水野 - 他：日整会誌。 $40 ： 1376,1964$ 。

8) O’Malley, A. G. : J. B. J. S. 41-B : 888 , 1959.

9) Carlos E. Ottolenghi, et al.: J. B.J. S. 44A : 855, 1962 .

10）嶋良宗：日整会誌. 48：159-167, 1974.

11）上野 - 他：整形外科. $16: 81,1965$.

12）横崎元男：臨整外. $6: 837,1971$.

\section{当教室における変形性股関節症の観血的治療 成績について}

熊大医学部整形外科学教室（指導：北川敏夫教授）

忽 那 龍 雄・石 川 浩一郎

伊 勢 紘 平・木 屋 博 昭

\section{A Follow up Study of the Surgical Procedures for Degenerative Osteoarthrosis of the Hip Joint}

By

T. Kutsuna, K. Ishikawa, K. Ise and H. Kiya

Department of Orthopedic Surgery

Kumamoto University Medical School

A follow-up study of 42 operations of the hip joints suffering from degenerative osteoarthrosis is presented. 